\title{
UPAYA MENINGKATKAN MINAT DAN KETERAMPILAN MEMBACA AL QUR'AN MELALUI KEGIATAN LESSON STUDY KELAS IX - F DI SMP NEGERI 2 TARAKAN
}

\author{
MARWAH \\ SMP Negeri 2 Tarakan \\ e-mail : saphari95@gmail.com
}

\begin{abstract}
ABSTRAK
Pada umumnya setiap peserta didik memiliki kemampuan, karakteristik, ciri, bahkan tingkah laku yang berbeda,hal ini sudah menjadi sunnatullah sehingga diantara mereka terdapat kelebihan dan kekurangan, dengan adanya perbedaan dan keragaman kemampuan pasti ada perbedaan di bidang akademik dan non akademik, termasuk dalam hal minat dan keterampilan. Dalam pembelajaran Pendidikan Agama Islam, ada salah satu indicator dan tujuan pembelajaran yang harus di capai oleh peserta didik untuk bisa membaca ayat-ayat al Qur'an dengan baik dan benar. Berdasarkan pengamatan, diantara peserta didik masih ada yang tidak bisa atau kurang mampu dalam hal membaca Al Qur'an dengan baik dan benar. Untuk mengatasi hal itu, harus ada langkah tepat dan cepat yang akan di lalukan oleh penulis agar peserta didik bisa semangat dan termotivasi dalam mengikuti pembelajaran, khususnya belajar membaca ayat -ayat Al Qur'an, sehingga tujuan pembelajaran dapat tercapai dengan baik. Langkah pertama yang akan di lakukan yaitu mengadakan perbaikan pada Rencana Pelaksanaan Pembelajaran( RPP) melalui penerapan kegiatan lesson Study. Dalam kegiatan Lesson Study ada tiga tahap yang akan di lakukan, yaitu tahap PLAN (merencanakan), tahap $D O$ (melaksanakan), dan tahap SEE (refleksi), ke tiga tahap ini di lakukan sekaligus dalam 1 siklus, dan di laksanakan secara berkelanjutan. Lesson Study merupakan salah satu cara yang efektif untuk memperbaiki proses pembelajaran yang bisa meningkatkan hasil belajar peserta didik.
\end{abstract}

Kata Kunci : Minat, Keterampilan, Baca Al Qur'an, lesson Study

\section{ABSTRACT}

In general, each student has different abilities, characteristics, characteristics, and even behavior, this has become sunnatullah so that between them there are advantages and disadvantages, with differences and diversity of abilities there must be differences in academic and non-academic fields, including in terms of interests and skills. In learning Islamic Religious Education, there is one indicator and learning goal that must be achieved by students, which must be able to read verses or suras in the Qur'an properly and correctly. able or less able in terms of reading the Qur'an properly and correctly. To overcome this, there must be appropriate and fast steps that will be taken by the author so that students can be enthusiastic and motivated in participating in learning, especially learning to read the suras in the Qur'an, so that learning objectives can be achieved properly. The first step to be taken is to make improvements to the Learning Implementation Plan (RPP) through the implementation of lesson study activities. In Lesson Study activities. There are three stages that are carried out, namely the PLAN stage (planning), DO stage (implementing), and the SEE stage (reflection), these three stages are carried out simultaneously in 1 cycle, and are carried out continuously. Lesson Study is an effective way to improve the learning process, which can improve student learning outcomes. Keywords: Interests, Skills, Reading the Qur'an, Lesson Study

\section{PENDAHULUAN}

Membaca al Qur'an dan mengamalkan isi al Qur'an merupakan kewajiban bagi setiap muslim dan muslimat, tidak sempurna dalam menjalani hidup apa bila seseorang tidak bisa membaca al Qur'an, oleh karna itu setiap muslim wajib baginya untuk bisa membaca Al Qur'an. Berdasarkan pengamatan penulis selama ini, kenyataan yang terjadi di setiap tingkatan kelas 
masih ada peserta didik yang tidak bisa membaca Al Qur'an dengan baik. Terlihat pada saat pelajaran berlangsung sebagian mereka sambil main-main,sepertiny tidak ada semangat dan gairah untuk pokus pada materi, tidak ada kesungguhan dalam mengikuti pembelajaran, terutama materi tentang bacaan ayat-ayat Al Qur'an, hal tersebut menggambarkan bahwa mereka kurang terampil dalam membaca Al Qur'an. Sementara tujuan pembelajaran mengharuskan peserta didik untuk bisa terampil membaca Al Qur'an dengan baik dan benar sesuai dengan makhraj huruf.

Perlu dimaklumi bahwa peserta didik yang tidak bisa membaca Al Qur'an dan tidak termotivasi untuk mempelajarinya, di pengaruhi 2 faktor yaitu factor intern dan factor ekstern, paktor intern yaitu factor dari anak itu sendiri yang memang tidak tertarik untuk belajar al Qur'an di sebabkan kurangnya pemahaman tentang pentingnya belajar membaca al Qur'an, yang kedua factor ekstern yaitu keadaan lingkungan yang tidak mendukung, (Slameto.2003). Orang tua kurang memperhatikan putra putrinya karna kesibukan-kesibukan mereka.

Dengan melihat kenyataan tersebut di atas, penulis terpanggil untuk meneliti dan membahas masalah ini, penulis bersama dengan guru-guru yang lain membahas langkah dan upaya yang harus di lakukan untuk bisa membangkitkan semangat pesetra didik dalam pembelajaran supaya termotivasi khususnya belajar membaca ayat-ayat Al Qur'an. Dalam diskusi bersepakat akan mencoba satu model kegiatan untuk memperbaiki proses dalam pembelajaran. yaitu melalui kegiatan lesson Study.

Berdasarkan kesepakatan penulis bersama tim Lesson Study, telah mengidentifikasi beberapa masalah yang menjadi dasar untuk di analisis dalam penelitian ini di antaranya : 1) Kurangnya minat peserta didik dalam belajar al Qur'an, 2) Rendahnya semanagat dan motivasi dalam membaca al Qur'an, 3) Kurangnya pemahaman tentang pentingnya membaca Al Qur'an. 4) Adanya peserta didik yang tidak bisa membara al Quran dengan baik. 5) Rendahnya nilai keterampilan dalam membaca ayat-ayat al Qur'an.

Dalam tahapan lesson Study, penulis secara bersama-sama mendesain Rencana Pelaksanaan Pembelajaran(RPP), mulai dari perencanaan, Plaksanaan pembelajaran, mengamati, dan refleksi. Lesson study adalah model bimbingan profesi pendidik dengan membahas pembelajaran secara bersama-sama dan berkesinambungan sesuai dengan prinsip mutual learning, sehingga komunitas belajar bisa terbentuk (Daryanto : 2012: 42 )

\section{METODE PENELITIAN}

Untuk meningkatkan hasil belajar peserta didik perlu ada upaya perbaikan, mulai dari perencanaan pembelajaran sampai kegiatan belajar di kelas. Dalam penelitan ini penulis sebagai guru model bersama tim Lesson Study atau observer sepakat menerapkan metode peer teaching atau Tutor Sebaya. Peer Teching adalah salah satu metode yang menjadikan siswa lebih semangat dan termotivasi dalam belajar,karna mereka merasa nyaman di bimbing dan di dampingi belajar bersama dengan teman sejawat.

Penulis sepakat dengan tim Lesson Study memilih metode tutor sebaya karna punya keunggulan -keunggulan diantaranya : meningkatkan motivasi belajar peserta didik, meningkatkan kualitas dalam proses pembelajaran, Interaktif sosial pesetra didik dalam pembelajaran, meningkatkan rasa tanggung jawab untuk belajar sendiri, dan meningkatkan hasil belajar peserta didik.

Menurut Arjanggi dan Suptihatin (2010), tutor ebaya adalah suatu metode pembelajaran yang di lakukan dengan cara memberdayakan sisa yang memiliki daya serap tinggidari kelompok siswa itu sendiri untuk menjadi tutor bagi teman-temannya, di mana siswa yang menjadi tutor bertugas untuk memberikan materi belajardan latihan kepada teman-temannya (tutee) yang belum faham terhadap materi atau latihan yang di berikan guru dengan di landasi aturan yang telah di sepakati bersamadalam kelompok tersebut, sehingga akan terbangun suasana belajar kelompok yang bersifat kooperatif bukan kompetitif

Menurut Winarno Surakhmad (1994:53), Tutor sebaya merupakan salah satu strategi pembelajaran untuk membantu memenuhi kebutuhan peserta didik, dan ini merupakan 
pendekatan kooperatif, yang saling menghargai dan mengerti serta bekerjasama diantara peserta didik. Penelitian ini dilakukan dalam 2 siklus dan setiap siklus mempunyai 3 tahapan, yaitu Plan, Do, dan See.

\section{HASIL DAN PEMBAHASAN}

Hasil

Sebelum pelaksanaan kegiatan Lesson Study, data awal yang ada menunjukkan bahwa keaktifan peserta didik Kelas IX-F yang berjumlah 32 baru mencapai 65,6 \% . sebagai mana yang tertera pada table 1 berikut :

Tabel 1. Data Keaktifan Peserta Didik Pada Kondisi Awal

\begin{tabular}{ll}
\hline \multicolumn{1}{c}{ Uraian } & Jumlah K.1 \\
\hline Siswa & 32 \\
2. Aktif & $2165,6 \%$ \\
3. Tidak aktif & $1134,4 \%$ \\
\hline
\end{tabular}

Data dari tabel 1 di atas membuktikan bahwa keaktifan belajar peserta didik termasuk dalam katagori kurang . Dengan demikian penulis masih memandang perlu untuk ditingkatkan lagi, dengan harapan semoga keaktifan peserta didik yang tinggi dalam mengikuti pembelajaran bisa meningkatkan hasil belajar yang lebih baik.

Karna kondisi keaktifan peserta didik yang masih kurang maka peneliti akan menyusun kembali Rencana Pelaksanaan Pembelajaran (RPP) yang bisa lebih mengaktifkan peserta didik dalam mengikuti pembelajaran. Setelah berdiskusi dengan teman serumpun, sepakat dan berencana akan memperbaiki proses pembelajaran melalui kegiatan Lesson Study.

Dari hasil observasi pada siklus 1 dan 2 terbukti bahwa pelaksanaan lesson Study mulai dari kegiatan plan, do, dan see sudah terlaksana dengan baik. Namun ada beberapa komentar / masukan dari observer yang dapat di lihat pada table 2 berikut :

Tabel 2 : Observasi Hasil Lesson Study,dan cek list Observer

\begin{tabular}{|c|l|c|c|c|c|}
\hline $\begin{array}{c}\text { N } \\
\text { O }\end{array}$ & \multicolumn{1}{|c|}{$\begin{array}{c}\text { Kegiatan } \\
\text { Pembelajaran }\end{array}$} & $\begin{array}{c}\text { Siklus } \\
\mathbf{1}\end{array}$ & $\begin{array}{c}\text { Komentar dan } \\
\text { masukan Observer }\end{array}$ & $\begin{array}{c}\text { Siklus } \\
\mathbf{2}\end{array}$ & $\begin{array}{c}\text { Komentar dan } \\
\text { masukan } \\
\text { Observer }\end{array}$ \\
\hline 1 & $\begin{array}{l}\text { Apakah peserta didik } \\
\text { sungguh-sungguh } \\
\text { berdoa pada saat } \\
\text { pembelajaran akan di } \\
\text { mulai }\end{array}$ & $100 \%$ & $\checkmark$ & $100 \%$ & $\checkmark$ \\
\hline 2 & $\begin{array}{l}\text { Apakah peserta didik } \\
\text { menjawab pertanyaan } \\
\text { guru, pada awal } \\
\text { pembelajaran / } \\
\text { apersepsi }\end{array}$ & $100 \%$ & $\checkmark$ & $100 \%$ & $\checkmark$ \\
\hline 3 & $\begin{array}{l}\text { Adakah peserta didik } \\
\text { yang tidak } \\
\text { memperhatikan pada } \\
\text { saat guru } \\
\text { mencontohkan } \\
\text { bacaan Surah As- } \\
\text { Zumar (39): 53 }\end{array}$ & 81,25 & $\begin{array}{l}\text { Ada 6 peserta didik } \\
\text { yang tidak } \\
\text { memperhatikan pada } \\
\text { saat guru } \\
\text { mencontohkan } \\
\text { bacaan Surah As- } \\
\text { Zumar (39): 53 }\end{array}$ & $\begin{array}{l}\text { Ada 3 peserta } \\
\text { didik yang tidak } \\
\text { memperhatikan } \\
\text { pada saat guru } \\
\text { mencontohkan } \\
\text { bacaan Surah An } \\
\text { Najm ( 53 ) Ayat } \\
\text { 39-42 }\end{array}$ \\
\hline 4. & $\begin{array}{l}\text { Adakah peserta didik } \\
\text { yang tidak }\end{array}$ & $\begin{array}{l}90,62 \\
\text { Ada 5 peserta didik }\end{array}$ & & \\
\hline
\end{tabular}


Vol. 1 No. 2 Desember 2021, e-ISSN : 2807-8667| p-ISSN : 2807-8837

\begin{tabular}{|c|c|c|c|c|c|}
\hline & $\begin{array}{l}\text { memperhatikan pada } \\
\text { saat teman lain } \\
\text { kelompok } \\
\text { membacakan Surah } \\
\text { As-Zumar (39): } 53\end{array}$ & $\begin{array}{l}84,37 \\
\%\end{array}$ & $\begin{array}{l}\text { yang tidak } \\
\text { memperhatikan } \\
\text { bacaan surah As- } \\
\text { Zumar (39): } 53\end{array}$ & $100 \%$ & \\
\hline 5 & $\begin{array}{l}\text { Adakah peserta didik } \\
\text { di setiap kelompok } \\
\text { yang tidak bisa } \\
\text { membaca Surah As- } \\
\text { Zumar (39): } 53 \text {. }\end{array}$ & $\begin{array}{l}81,25 \\
\%\end{array}$ & $\begin{array}{l}\text { Ada } 3 \text { kelompok } \\
\text { yang masing -masing } \\
\text { ada } 2 \text { anggotanya } \\
\text { tidak bisa } \\
\text { membaca surah } \\
\text { As-Zumar (39): } 53\end{array}$ & $\begin{array}{l}93,75 \\
\%\end{array}$ & $\begin{array}{l}\text { Ada } 2 \text { kelompok } \\
\text { yang masing- } \\
\text { masing } 1 \\
\text { anggotanya tidak } \\
\text { bisa membaca } \\
\text { Najm ( } 53 \text { ) Ayat } \\
\text { 39-42 }\end{array}$ \\
\hline 6 & $\begin{array}{l}\text { Apakah peserta didik } \\
\text { ( tutor) yang sdh } \\
\text { dipilih sebelumnya } \\
\text { bisa membimbing } \\
\text { temannya dalam } \\
\text { belajar membaca } \\
\text { Surah As-Zumar } \\
\text { (39): } 53\end{array}$ & $100 \%$ & $\checkmark$ & $100 \%$ & $\checkmark$ \\
\hline 7 & $\begin{array}{l}\text { Apakah semua } \\
\text { peserta didik } \\
\text { mendapat giliran } \\
\text { untuk } \\
\text { memperaktikkan } \\
\text { membaca Surah As- } \\
\text { Zumar (39): } 53\end{array}$ & $100 \%$ & $\checkmark$ & $100 \%$ & $\checkmark$ \\
\hline 8 & $\begin{array}{l}\text { Apakah ada kerja } \\
\text { sama yang baik antar } \\
\text { peserta didik dalam } \\
\text { kelompok, }\end{array}$ & $100 \%$ & $\checkmark$ & $100 \%$ & $\checkmark$ \\
\hline 9 & $\begin{array}{l}\text { Apakah metode yang } \\
\text { di gunakan guru } \\
\text { sudah terlaksana } \\
\text { sesuai perencanaan }\end{array}$ & $100 \%$ & $\checkmark$ & $100 \%$ & $\checkmark$ \\
\hline 10 & $\begin{array}{l}\text { Apakah guru sudah } \\
\text { melaksanakan semua } \\
\text { perannya sesuai } \\
\text { perencanaan }\end{array}$ & $100 \%$ & $\checkmark$ & $100 \%$ & $\checkmark$ \\
\hline
\end{tabular}

\section{Pembahasan}

Setelah kegiatan belajar mengajar terlaksana pada siklus I dan II terlihat pada table diatas bahwa ada 10 nomor aktivitas dalam kegiatan pembelajaran yang di oservasi di setiap siklus. Terlihat di kolom komentar banyak yang terisi tanda cek list, hal ini menunjukkan bahwa pelaksanaan kegiatan Lesson Study sudah terlaksana dengan baik. Terbukti adanya perubahan perilaku yang lebih aktif dari peserta didik dari siklus I ke siklus II. Peningkatan perilaku yang lebih aktif dari peserta didik tersebut dalam mengikuti pembelajaran terjadi karna setiap tahap pertemuan guru model dan tim Lesson Study selalu berupaya untuk melakukan perbaikanperbaikan atau merevisi RPP.

Berdasar dari hasil pengamatan di siklus I menunjukkan bahwa metode yang di terapkan dalam penelitian ini sudah menunjukkan hasil yang terbaik. Keaktifan belajar peserta didik pada kondisi awal yang berjumlah 32 peserta didik hanya mencapai $65,6 \%$ Setelah pelaksanaan 
siklus I, dan siklus II, menunjukkan bahwa keaktifan peserta didik meningkat, dari 32 peserta didik yang tidak memperhatikan pada saat guru mencontohkan bacaan Surah As- Az Zumar (39) ayat 53 ada 6 dan yang aktif 26 peserta didk ,jadi sekitar 81,25\%.ketercapaian. Peserta didik yang tidak memperhatikan pada saat teman lain kelompok membacakan Surah As-Zumar (39): 53, ada 5 dan yang aktif ada 27 peserta didik, Jadi keberhasilan sudah tercapai sekitar 84,3\%. Peserta didik dari setiap kelompok yang tidak bisa membaca Surah As-Zumar (39): 53, pada saat di di tugaskan oleh guru ada 6 peserta didik, dan yang aktif ada 26 peserta didik jadi sekitar $81,25 \%$ ketercapaian.

Berdasarkan cek list Observer di siklus II, masih Ada 3 peserta didik yang tidak memperhatikan pada saat guru mencontohkan bacaan Surah Najm ( 53 ) Ayat 39-42, dan yang aktif ada 29 peserta didik,jadi ketercapaian sudah mencapai 90,62\%.jadi dari siklus I ke siklus II ada kenaikan 9,37\%. Selain itu masih ada 2 kelompok yang masing-masing 1 anggotanya masih ada yang tidak bisa membaca Surah Najm (53) Ayat 39-42, dan yang sudah lancar bacaannya suda menvapai 30 peserta didik, hal ini menunjukkan tingkat keberhasian sudah mencapai 93,75 \%. Jadi ada kenaikan 12,50\% dari siklis I ke siklus II. Dari segi ke aktifan dan kelancaran baca Surah As-Zumar (39): 53 dan Surah Najm (53) Ayat 39-42.

Berkat penerapan kegiatan lesson study terdapat banyak kelebihan dan sangat bermanfaat bagi guru sebagai sarana pembelajar. Dengan bersama-sama guru model dan tim Lesson Study sebagai Observer merancang jalannya pembelajaran, sehingga guru bisa memaksimalkan kompetensi yang dimiliki. Kegiatan Lesson Study dapat mengubah proses pembelajaran yang biasa menjadi proses belajar yang menarik ,sehingga bisa menumbuhkan minat serta memotivasi peserta didik untuk lebih semangat belajar, khususnya belajar membaca al Qur'an, dan menjadikan peserta didik belajar lebih aktif dari sebelumnya.

Lesson Study termasuk salah satu pendekatan yang digunakan untuk meningkatkan kompetensi guru dalam memenej proses pembelajaran di kelas, dengan harapan peserta didik bisa lebih termotivasi dan semangat dalam mengikuti pembelajaran, agar tujuan pembelajaran bisa tercapai dengan maksimal.

Berdasarkan Kopp (Sudarmanto, 2000:9) Lesson Study merupakan aktivitas meningkatan kompetensi professional guru yang di kembangkan dengan terstruktur oleh pendidikan jepang yang mempunyai misi untuk mengembangkan aktivitas pembelajaran lebih stabil dan efektif. Lesson study merupakan suatu proses kolaboratif pada sekelompok pendidik dalam mengidentifikasikan suatu masalah pembelajaran yang terkadang ditemukan di kelas, serta merancang suatu skenario pembelajaran yang akan dilaksanakan di kelas,dan dilakukan berdasarkan shering dari guru model bersama guru -garu observer. Lesson Study menekankan pada kualitas hasil belajar peserta didik, serta tujuan pembelajaran dijadikan focus dan titik perhatian utama dalam kelas.

\section{A. Perencanaan (Plan)}

Kegiatan plan (perencanaan) dilakukan di diruang Lab IPA SMP N.2 Tarakan bersamasama guru model dan Tim Lasson Study, Kegiatan ini bertujuan untuk menghasilkan rancangan pembelajaran yang diyakini mampu membelajarkan peserta didik secara efektif .Dalam perencanaan ini, guru secara kolaboratif berbagi ide menyusun rancangan pembelajaran untuk menghasilkan cara-cara pengorganisasian bahan ajar, proses pembelajaran, maupun persiapan alat bantu pembelajaran.

Sebelum diimplementasikan dalam kelas, rancangan pembelajaran yang telah disusun kemudian disimulasikan. Pada tahap ini ditetapkan prosedur pengamatan dan instrumen yang diperlukan dalam proses pembelajaran. Kegiatan perencanaan ini dilaksanakan selama 2 kali yaitu pada tanggal 25 Oktober dan tanggal 1 November 2021. Rancangan tersebut disusun dalam Rencana Pelaksanaan Pembelajaran (RPP) dengan Standar Kompetensi: "Ayat-ayat Al Qur'an dan Hadits tentang Optimis, Ikhtiar dan Tawakal. Materi pokok Surah Az Zumar (39) ayat 53, Surah An Najm (53) Ayat 39-42, Surah Ali Imran (3) ayat 159”. Metode pembelajaran yang dipergunakan adalah metode Peer teaching / tutor sebaya, dan metode tanya jawab . 
Pada tahap Plan, RPP disusun oleh guru model bersama tim observer. RPP yang sudah disusun selanjutnya di presentasikan untuk diamati oleh para observer. Kemudian guru model memberikan kesempatan kepada observer untuk memberikan masukan demi kesempurnaan RPP, supaya menghsilkan cara-cara pengorganisasian bahan ajar yang tepat sebelum diimplementasikan di dalam kelas. RPP yang sudah diamati dan di revisi bisa langsung diterapkan atau dilaksanakan di kelas, sehingga tujuan awal yakni membelajarkan peserta didik untuk meningkatkan minat,semangat serta keterampilan dalam hal membaca Al-Qur'an dapat tercapai dengan baik.

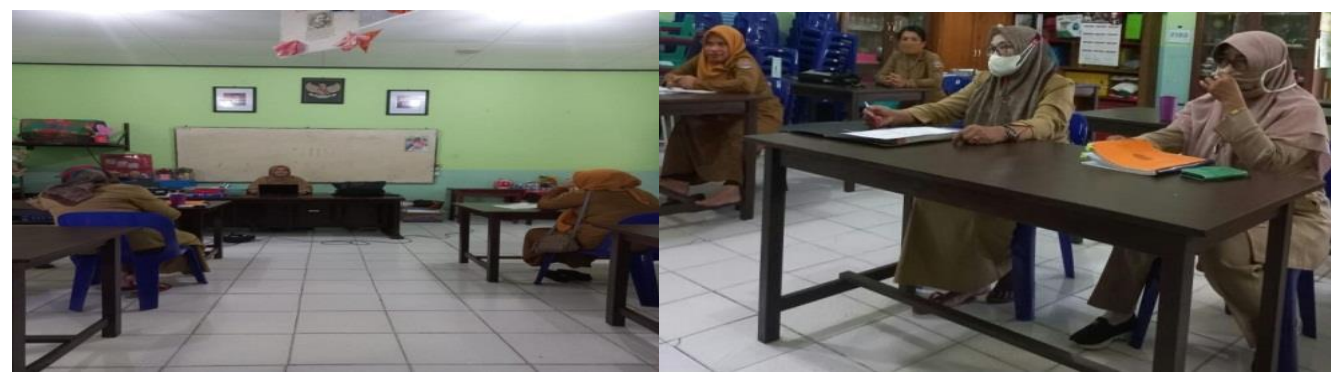

Gambar 1. Kegiatan Plan

\section{B. Pelaksanaan (Do)}

Tahapan do dilaksanakan selama 2 kali pertemuan ( 2 siklus) yaitu pada tanggal 26 Oktober,dan tanggal 2 November 2021 di SMP Negeri 2 Tarakan. Penelitan ini di laksanakan di kelas IX - F dengan jumlah 32 peserta didik. Open class dihadiri oleh guru-guru Observer SMP Negeri 2 Tarakan. Sebanyak 4 orang guru. Pada tahapan do (pelaksanaan), kegiatan yang dilakukan yaitu menerapkan rancangan pembelajaran yang telah dibuat pada tahap plan. Penulis bertindak sebagai guru model sedangkan guru-guru yang lain bertindak sebagai pengamat (observer).

Pengamatan yang dilakukan oleh para observer diarahkan pada aktivitas belajar peserta didik dengan berpedoman pada aturan yang sudah di sepakati sebelumnya. Satu hari sebelum pelaksanaan (do), guru model membagi siswa menjadi 6 kelompok. Satu kelompok terdiri dari 5 peserta didik yang heterogen, dan ada 2 kelompok anggotanya 6. Masing-masing kelompok kemapuannya berbeda-beda, dan sudah diatur dari yang berkemampuan A (pandai), B (sedang), C (kurang).

Berdasarkan pembagian kelompok, sudah ditugaskan bagi peserta didik yang berkemampuan A bisa membimbing kelompoknya yang berkemampuan B dan C, di setiap kelompok sudah diberi tugas masing-masing, dan secara bergiliran di setiap kelompok mempresentasikan bacaan ayat-ayat Al Qur'an yang sudah di siapkan, yaitu Surah Az Zumar ( 39) ayat 53,Surah An Najm ( 53 ) Ayat 39-42, dan Surah Ali Imran( 3) ayat 159. Dengan pelaksanaan metode peer teaching, peserta didik nampak serius dan semangat mengikuti proses pembelajaran, sebagaimana tertera pada gambar berikut.
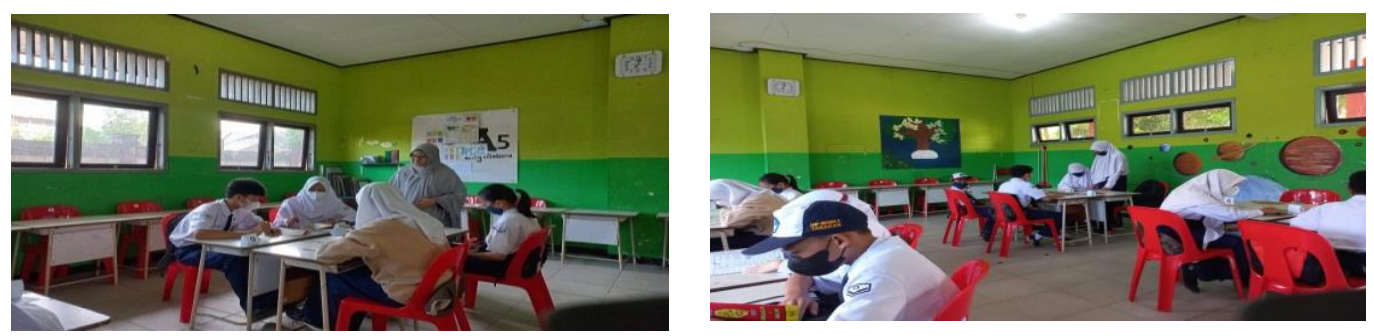

Gambar 2. Pelaksanaan $D O$ 

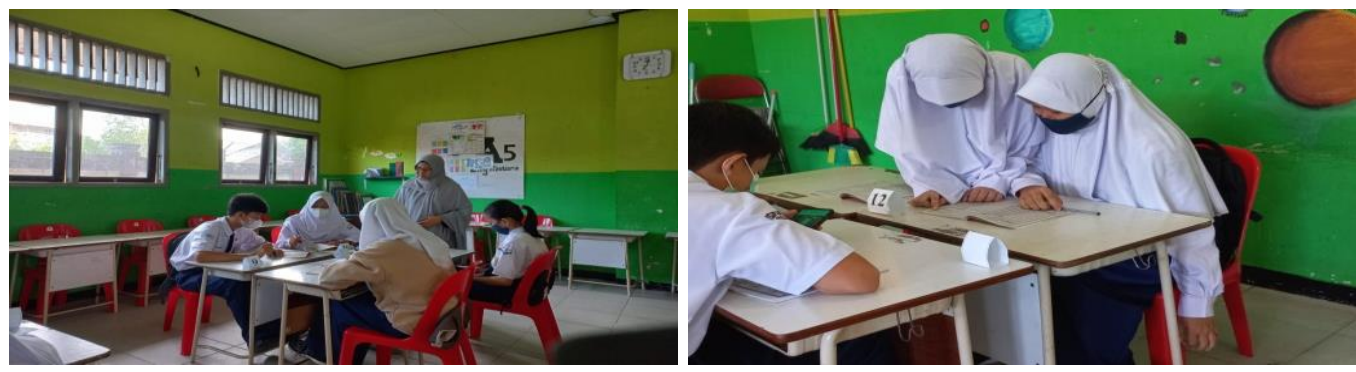

\section{Refleksi (See)}

Kegiatan see adalah kegiatan sebagai refleksi pembelajaran yang sudah berlangsung. Di kegiatan ini, moderator memberi kesempatan terlebih dahulu pada guru model untuk mengungkapkan keadaan dalam kegiatan pembelajaran di kelas yang sudah dilaksanakan. Selanjutnya diberikan kekesempatan kepada masing-masing observer untuk memberikan masukan atau kritikan, dan saran dalam rangka peningkatan kualitas pembelajaran yang disampaikan secara bijak tanpa merendahkan guru yang membelajarkan. Masukan yang positif dapat digunakan untuk merancang kembali pembelajaran yang lebih baik lagi. Dengan adanya kegiatan lesson Stady ini, guru model merasa terbantu, mulai dari penyempurnaan RPP sampai dengan proses pembelajaran di kelas. Lesson Study dapat meningkatkan profesionalisme guru dalam pelaksanaan pembelajaran yang akan mengarah pada peningkaran kualitas dan hasil belajar siswa yang lebih baik.

Styler dan Hiebert ( Susilo,2009:3) mengatakan bahwa : Lesson Study adalah suatu proses kolaboratif pada sekelompok ketika mengidentifikasikan masalah pembelajaran, merancang suatu skenario pembelajaran (yang meliputi kegiatan mencari buku artikel mengenai topik yang akan di ajarkan), memebelajarkan peserta didik sesuai dengan skenario (salah seorang guru melaksanakan pembelajaran sedangkan yang lain mengamati), mengevaluasi dan merevisi scenario pemelajaran, membelajarkan lagi skenario pembelajaran yang telah di revisi, mengevaluasi lagi pembelajaran dan membagikan hasilnya dengan guruguru lain (mendiseminasikannya )

Kegiatan lesson Study adalah model pembinaan (pelatihan) profesi pendidik melalui pengkajian pembelajaran secara kolaboratif dan berkelanjutan berdasarkan prisip-prisip kolegalitas dan mutual lerning untuk membangun komunitas belajar (Summar Hendayana,dkk, 2009: 5).

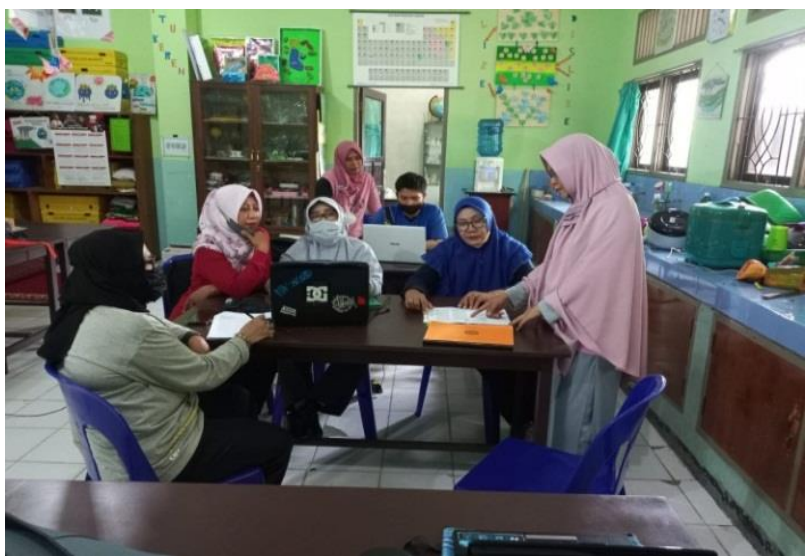

Gambar 3.Pelaksanaan See

\section{KESIMPULAN}

Lesson Study dirasakan banyak membawa manfaat bagi penulis yang bertugas sebagai guru model, dan termasuk bagi para observer, karna dalam kegiatan Lesson Study terjadi suasana saling belajar dan membutuhkan, terutama dalam proses perencanaan penyusunan RPP 
pada waktu kegiatan Plan, di kegiatan ini saling melengkapi, kekurangan dan kritik yang membangun sehingga tersusun RPP yang mendekati sempurna, selanjutnya akan dilaksanakan pada saat open class oleh guru model. Sedangkan guru lain membantu sebagai observer. Guru yang menjadi observer selain mengamati keaktifan peserta didik dalam proses pembelajaran yang berlangsung, juga mengamati cara guru model mengajar, yang nantinya bisa diterapkan di kelas masing-masing. Lahirnya Rencana Pelaksanaan Pembelajaran (RPP) sebagai hasil perbaikan dari kegiatan Plan,do,dan see yang bertujuan untuk meningkatkan minat, semangat, dan motivasi peserta didik dengan bermuara pada kualitas hasil belajar yang lebih baik.

\section{DAFTAR PUSTAKA}

Arjanggi, R dan Suprihatin, T. (2010). Metode Pembelajaran Tutor Sebaya. Meningkatkan Hasil Belajar Berdasar Regulasi Diri. Makara Sosial Humaniora.

Hendayana, summar. (2006). Lesson Study suatu Strategi untuk meningkatkan keprofesionalan pendidikan(Pengalaman IMSTEP-JICA). Bandung: UPI Press.

Kementerian Pendidikan dan Kebudayaan Republik Indonesia (2015). Pusat Kurikulum dan Perbukuan ,Balitbang,Kemendikbud.

Muhammad. (2012). Pendidikan Anak Dalam Islam, terj. M.Harun. Jakarta: Darul Haq.hlm.5

Menteri Agama RI,CV Asy Syifa Semarang. (1999). Al Qur'an dan Terjemahannya (Revisi terbaru )

Richardson, J (2006). Lesson Study: Teacher Learn how to improve.Instruction. National Staf Development Council. ( Online):http://www.nsdc.org03/05/2006

Sudrajad, Ahmad. (2008). Lesson Study untuk Meningkatkan Proses dan Hasil Pembelajaran. https://akhmadsudrajat.wordpress.com/2008/02/22/lesson-study-untukmeningkatkan-pembelajaran/. Diakses pada, 14 November 2015.

Suyanto dan Jihad (2014). Menjadi Guru Profesional .( Strategi Meningkatkan Kualifikasi dan Kualitas guru di Era Global) .Bandung : Esessi

Slameto (2003). Belajar dan factor-faktor yang mempengaruhinya.Jakarta: PT.Rineka Cipta.

Stigler, J, dan Hiebert, J. (1999).The Teaching: Best Ideas form WordsTeacher for Improving Esucation in the Classroom.New York: Summit Books.

Tim Penyusun Fakultas Tarbiah UIN Sunan Kalijaga Yogjakarta. (2005). Panduan Praktis Mengajar Pendidikan Agama Islam.

Tepanek, J (2003a). "Researchers in Every Classroom". Northwest Teacher. Spring. https://id.wikipedia.org/wiki/Lesson_study 